\title{
Metaphors Trump Lives by: A Critical Metaphor Analysis of Trump's Statements in 2020 Presidential Election Debates
}

\author{
Chunxi Zhu ${ }^{1}$ \\ ${ }^{1}$ Department of Linguistics, School of International Studies, Zhejiang University, Hangzhou, China \\ Correspondence: Chunxi Zhu, Department of Linguistics, School of International Studies, Zhejiang University, \\ Hangzhou, 310058, China. E-mail: zcx2019@zju.edu.cn
}

Received: January 22, 2021

Accepted: February 25, 2021

Online Published: February 28, 2021

doi:10.5539/ijel.v11n2p150

URL: https://doi.org/10.5539/ijel.v11n2p150

\begin{abstract}
Critical Metaphor Analysis (CMA) helps to define the relationship between metaphor, power, ideology and cognition by recognizing conceptual metaphors in text or discourse. This thesis built a metaphor-centered analytical framework which connects discourse, cognition and ideology to investigate metaphors in Trump's discourses in the 2020 Presidential Election Debates, which shed light upon cognitive structure and ideology behind his discourse. To win more votes, Trump managed to magnify Republican Party's contribution while masking its defects, exaggerate the disadvantages of the Democratic Party while concealing its merits. Meanwhile, he declared himself one who represents the interests of ordinary people and to fight for their interests. Besides, his "patriotism" and "exclusiveness" also reflected populism characteristics.
\end{abstract}

Keywords: critical metaphor analysis, Donald Trump, ideology square, ideology, cognitive structure

\section{Introduction}

Donald Trump, the previous US President, is a loyal user of metaphor. Metaphors ubiquitously appear in his discourse, no matter public speeches or TV debates, to express views on domestic and international affairs and preach his political advocacy.

More than a rhetorical technique and a linguistic device for modifying discourse, metaphor is believed to a manifestation of cognitive processes of human beings. By constructing the theory of conceptual metaphor, Lakoff and Johnson (2003) explained the cross-domain mapping mechanism and revealed the role of metaphor in the process of cognition. Charteris-Black attempted to combine cognitive methods with metaphors. He introduced critical metaphor analysis (CMA), and believed that by identifying conceptual metaphors in texts or discourses, combining language, cognition, and pragmatic dimensions, one can clarify metaphors' relationship to power (discourse power), ideology (value beliefs, etc.) and cognition (Charteris-Black, 2004).

Existing studies mainly focused on pragmatic analysis and highlighted the persuasive function of metaphor and Trump's ideology in his public speeches and TV debates (Harb \& Serhan, 2020; Bonilla, 2020). Quite a few researches have noticed the metaphor in Trump's discourse to explore his ideology (Mohammadi \& Javadi, 2016; Garcia, 2017; Pilyarchuk \& Onysko, 2018). All these analyses remain in the shallow level, and hardly explore the deep level of ideology and cognitive structure reflected by metaphors. Moreover, the distance between discourse producers and recipients can also be used as a tool to reveal ideology. This study attempts to investigate Trump's cognitive structure reflected by metaphors in Trump's discourse and explore his ideology with help of the ideology square theory. To achieve this research goal, the following issues will be addressed:

1) What types of metaphors do Donald Trump tend to employ in political genres such as the 2020 Presidential Election Debates?

2) What relationship between language, power and ideology do these metaphors reveal?

3) How does Donald Trump use metaphors to construct cognition structure in order to achieve specific purposes?

\section{Literature Review}

Critical discourse analysis (CDA) emerged as a network of scholars in the early 1990s (Wodak \& Meyer, 2008). Wodak and Meyer believed that the common interest of various research methods of CDA is to uncover the relationship between discourses and ideology and power through the systematic study of corpus. Recently, a 
large number of CDA researchers have adopted corpus linguistic analysis to reduce the subjective judgments in the research design and interpretation of results in that information provided by corpus is quantitative. By analyzing semantic aura, semantic prosody by means of frequency table, keyword retrieval, display collocation, etc. in corpus software, it is possible for CDA to carry out quantitative and qualitative analysis on data.

$\mathrm{CDA}$ is a research method to do research on the use of social power, dominance and inequality through the texts and discourses under the social and political contexts, mining the ideology implied in the language (van Dijk, 2001). By analyzing the characteristics of language and social and cultural background, CDA may shed light upon the complex relationship between discourse, power and ideology.

From the domestic and foreign research, Critical Discourse Analysis is a vital perspective to analyze the discourse of political figures. CDA linguists have interest in the relationship between discourse and power. Discourse is socially constitutive but in turn constrained by society (Wodak \& Meyer, 2008). Due to its influences on society, discourse triggers important issues of power. Language and power are not subordinate, but language can be used to challenge power, to subvert it through which the distributions of power is altered (Wodak \& Meyer, 2008). The power struggles reflected in discourse mainly focus on gender, ethnicity, race, and class. CDA was used to uncover social power relations, process of power operation, asymmetry of power and power resistance reflected in political discourses and political documents (Woodside-Jiron, 2004; Lamb, 2013; Caballero-Mengibar, 2015). On the other hand, discourse and ideology are closely related. Language is a material form of ideology (Fairclough, 1995). Researchers pay close attention to ideology in political discourse for political figures often implicate their ideology backgrounds in their words (Bayram, 2010). With the help of CDA, ideology of political figures can be revealed and they can be distinguished from each other (Bhatia, 2006; Dirven, Polzenhagen, \& Wolf, 2005). In practice, the process of the speaker using discourses to persuade the audience is actually a process of manipulating the audience's mind. That is to say, the manipulation of language means the manipulation of the mind (van Dijk, 2005). CDA analyzes the process where discourse users resonate with and manipulate listeners to complete their ideological persuasion and legalization in a political setting (Wodak \& Meyer, 2008; Oppermann \& Spencer, 2013; Xin \& Liu, 2017). Combining Critical Discourse Analysis, corpus Analysis, pragmatics and cognitive linguistics, Charteris-Black (2004) introduced Critical Metaphor Analysis as an approach which intends to reveal the covert (and possibly unconscious) intentions of language users. Critical Metaphor Analysis (CMA) focuses on exploring the relationship between metaphor, cognition and ideology. According to the three-dimensional analytical model of CDA proposed by Fairclough (1995), Charteris-Black summarized three steps of metaphor analysis: (1) textual metaphor recognition; (2) implicit description at the language level; (3) implicit interpretation in social aspect.

Critical Metaphor Analysis supplements the cognitive view by taking particular metaphor choices into consideration (Charteris-Black, 2004). Metaphor is inseparable from the process of cognition (Hart, 2008; Lakoff \& Johnson, 2003). Metaphor exists in the conceptual system of human beings, which controls daily thinking and action. To a considerable degree, people construe the world through conceptual metaphors. Concept of social cognition could be expanded through the idea that conceptual metaphor is a unique cognitive tool that shapes social thought and attitudes (Landau, Mark, \& Meier, 2010). Lakoff and Johnson (2003) defined that phenomenon that inference patterns from one conceptual domain to another as conceptual metaphor, and named the systematic correspondences across such domains metaphorical mappings. Source domain, target domain and mapping constitute the most basic elements of conceptual metaphor. Metaphors map the structure, relationships, characteristics, and knowledge of the source domain onto the target domain (Lakoff \& Turner, 1989). On this basis, conceptual metaphor could be generally divided into three categories: orientational metaphor, ontological metaphor and structural metaphor (Lakoff \& Johnson, 2003): Orientational metaphors organize the whole conceptual system according to another concept related to spatial orientation: up and down, inside and outside, front and back, on and off; Ontological metaphor provides a basis for people to describe parts of experience as discrete entities or as unified classes of matter; Structural metaphor refers to the use of familiar concrete and simple descriptive structures to construct another abstract concept ( $\mathrm{Li} \& \mathrm{Li}, 2011$ ).

Metaphor is central to Critical Discourse Analysis. Since it could convey the evaluation persuasively, it is considered to constitute part of the ideology of texts. Thus, critical metaphor analysis can expose the intention of the language user and the power and ideology behind it. Critical analysis of the contexts of metaphors may reveal the underlying intentions of the text producer and therefore serve to identify the nature of particular ideologies (Charteris-Black, 2004).

Donald Trump is a world-famous politician whose political words have attracted the attention of many researchers. Through the method of CDA, the relationship between Trump's discourse and ideology is comprehensively evaluated. Researchers also evaluated his discourses at different times in order to not only 
discover his discourse structures but also reveal his ideological structures and use of power (Harb \& Serhan, 2020; Bonilla, 2020). Some scholars have noticed the metaphors in Trump's discourse, which indicates that the research on his discourse has reached the cognitive level. Through the analysis of metaphors, it can be found that Trump's ideology is implied in his words (Mohammadi \& Javadi, 2016). By establishing a cross-domain mapping in metaphors, Trump managed to construct an image of a successful leader and worthy candidate to win more votes (Garcia, 2017; Pilyarchuk \& Onysko, 2018). Meanwhile, Trump always attempted to strike a chord with the public in order to achieve his own political goals. He conveyed his intention to listeners through metaphors, influencing the public's emotions (Wang, 2019). Thus, during the Presidential Election times, he could achieve the purpose of persuasion and expression and win more votes (Duban, 2018; Heritage, 2018; Wu, Gong, \& Song, 2020).

The persuasive function of Trump's discourse was considered in some studies. According to systemic functional grammar, some studies consider the different persuasive effects of using different parts of speech. Halliday (2000) held that language has three meta-functions: ideational, inter-personal and textual. The transitive system in the functional grammar of the system is an infusive method in political discourse. The widespread use of the first person benefits in drawing people's hearts to win more support for the government. Grammatical forms such as transitivity, modality, personal pronouns, and passiveness influence the psychological distance between the discourse user and the recipient. Simple words are easily understood and accepted by the audience. These factors in Trump's discourse help narrow the gap with the audience, resonate in the audience's mind, and unite their ideas, so that he can more smoothly come up with his policies (Zhang, 2017; Jian, 2018).

Up to date, the investigations into Trump's discourse mainly have mainly relied on critical discourse analysis, with prevailing focus on the relationship between discourse and ideology through the analysis of metaphors. However, when taking ideology into account in the process of reflecting in the discourse, the connection between discourse and power ought not be ignored. Besides, though some scholars notice that the distance between discourse producers and recipients reflected by different discourses, they only consider the influence on persuasive function caused by the psychological distance. The source of this psychological distance still remains unknown. To overcome deficiencies mentioned above, this study attempts to combine quantitative and qualitative analysis to deeply discuss the cognitive construction of Trump's metaphors in his political discourses and explore his ideology in the light of the ideology square theory.

\section{Methodology}

There is a close relationship between discourse, cognition and ideology, and metaphor serves as an interface among them. Ideology is cognitive. Van Dijk (1998) claimed that through complex and long-term processes of socialization and other forms of social information processing, members of social groups, organizations or institutions cultivate shared social cognitions. In addition, ideology is an integral and abstract mental system, which forms this shared social attitude. Metaphor is a means of expressing ideology. Hans-Georg Wolf and Frank Polzenhagen (2003) observed that the systematicity of metaphor and ideology is interrelated, and the choice of metaphor reflects the specific intention and ideology of the text producer. The relationship between discourse and ideology cannot be severed. Purvis and Hunt (1993), by focusing on the practice of discourse, believed that the theory of ideology is a supplement to the theory of discourse. Ideology has the effect of discourse. Although there are no ideological markers in the general attributes of language and discourse, discourse analysis is a powerful tool for studying the structure and function of "latent" ideology (van Dijk, 2006).

Therefore, this study proposes an analytical framework which focuses on metaphor and connects discourse, cognition and ideology, as shown in Figure 1.

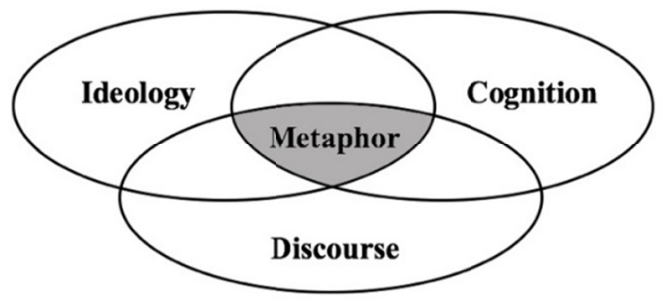

Figure 1. Framework of Discourse, Cognition and Ideology based on Metaphor 
Critical discourse analysis can expose the intention of the language user and the power and ideology behind it. Metaphor analysis is divided into three stages: Description, interpretation and explanation (Fairclough, 1995). See Figure 2. Based on this theory, Charteris-Black (2004) proposed this process as: identification, interpretation and explanation.

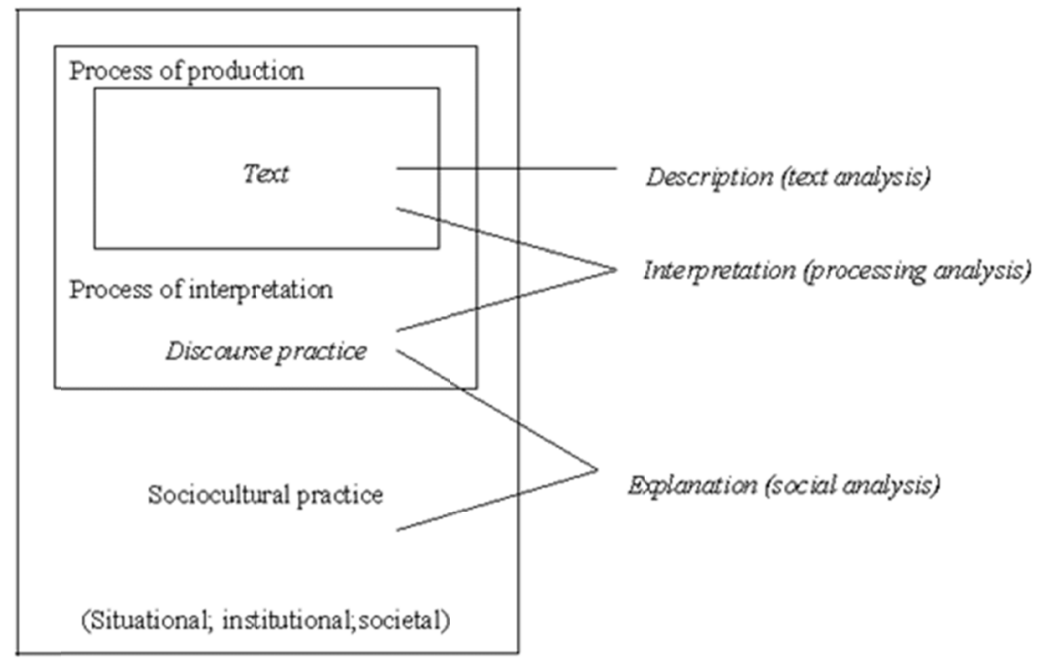

Figure 2. Dimensions of discourse and discourse analysis (Fairclough, 1995)

The priority of metaphor analysis is metaphor identification, more precisely, the chief task is to determine whether each word uses metaphorical or literal meaning. The identification of metaphors first requires careful reading of the target discourse to identify candidate metaphors that establish the cross-domain mapping relationship between target domain and source domain, after which you will proceed to the next qualitative phase and check the context for final confirmation. The Metaphor Identification Procedure (MIP) by the Pragglejaz Group in 2007 contributes a lot to achieving this process. Specific steps are as follows: (1) Read though the text/discourse before forming a general comprehension of its meaning. (2) Lexical units in the text/discourse are ascertained. (3) The meaning of each lexical unit is confirmed in context to explore how it applies to the entity, relationship, or attribute (i.e., contextual meaning) in the context triggered by the text/discourse. Through taking what comes before and after the lexical unit into consideration, each lexical unit' meaning is evaluated to determine where a more basic contemporary meaning exists, in the given context or in other contexts. (4) When the meaning of a lexical unit in given context is not the most basic one, but could be understood by comparing with the basic one, this lexical unit could be marked as a metaphor (The Pragglejaz Group, 2007). The procedure of metaphor identification discusses the context of word in text/discourse to distinguish whether its meaning is metaphorical or purely literal, which provides an operational method for discerning all metaphors in actual use. The second step is the interpretation of metaphors, including determining conceptual metaphors and conceptual keys. This process triggered to be qualitative involves establishing a relationship between metaphors and the cognitive and pragmatic factors that determine them (Charteris-Black, 2004). This conceptuality of metaphor provides the basis for establishing a cross-domain mapping between the source domain and the target domain. The explanation of metaphor involves the meaning of discourse, that is, the interrelationship between metaphors and the correlation between metaphor and context. With the help of ideological square, the reasons for the formation of specific concepts can be explored, including the influence of individual factors on the choice of specific metaphors, and deepest agent of social context and potential ideology.

Metaphors reflect ideology in the social conflicts between different interest groups. Van Dijk (1998) claimed that metaphors are selected to attract the attention of the recipients and lead to persuasive communication. Among different interest groups, "Our" groups are usually represented positively, and a negative way is always used to establish the ideological image of "their". Wodak (2002) pointed out that there are both positive self-representation and negative other-representation in any discourse. Van Dijk (1998) introduced a theoretical concept, ideology square, whose main strategies could be summarized into four aspects: accentuating the positive aspects of "us", minimizing the positive aspects of "them", minimizing the negative aspects of "us" and accentuating the negative aspects of "them". 
Table 1. van Dijk's concept of ideology square

\begin{tabular}{ll}
\hline Accentuate positives of "us" & Minimize negatives of "us" \\
\hline Minimize positives of "them" & Accentuate negatives of "them" \\
\hline
\end{tabular}

Metaphors have very high frequency of occurrence in Trump's words. Trump uses metaphors to convey his political views and pursued listeners. Trump's statements in the 2020 Presidential Election Debates were selected as research materials to reveal his ideology and cognitive structure. 117 Metaphors are identified by MIP and mainly classified into six catalogues according to their different concepts.

The identification and classification of metaphor types allows us to figure out which types of metaphors Donald Trump tends to employ in political genres such as the 2020 presidential election debates. With the help of the ideological square, it is possible to reveal the relationship between language, power and ideology in Trump's discourse as well as to explore how he construct cognitive structures to achieve specific political goals.

\section{Results and Discussion}

With the help of MIP, all the involved metaphors in Trump's discourses in the 2020 Presidential Election Debate are identified, and then divided into seven categories according to the source domain. As it is demonstrated in the first column of Table 2, they are military metaphor, construction metaphor, heroic metaphor, machine/technology metaphor, crime metaphor, animal metaphor and climate metaphor. Metaphor keywords in each source domain, token which is the sum of frequency of each keyword and proportion are illustrated in the following columns.

Table 2. Metaphors in Donald Trump's discourses in the 2020 presidential election debate

\begin{tabular}{|c|c|c|c|c|c|c|}
\hline & & $\begin{array}{l}\text { First } \\
\text { Presidential } \\
\text { Election } \\
\text { Debate } \\
\end{array}$ & & $\begin{array}{l}\text { Second } \\
\text { Presidential } \\
\text { Election } \\
\text { Debate }\end{array}$ & & \\
\hline Metaphor Category & $\begin{array}{l}\text { Metaphor } \\
\text { Keywords }\end{array}$ & Token & $\begin{array}{l}\text { Metaphor } \\
\text { Keywords }\end{array}$ & Token & Total & Proportion \\
\hline Hero metaphor & $\begin{array}{l}\text { job, great job, } \\
\text { great, save, } \\
\text { miracle }\end{array}$ & 21 & $\begin{array}{l}\text { job, great, disaster, } \\
\text { save, work, } \\
\text { successful, success }\end{array}$ & 21 & 42 & $36.21 \%$ \\
\hline Construction metaphor & $\begin{array}{l}\text { build, } \\
\text { building, } \\
\text { rebuild, } \\
\text { destroy }\end{array}$ & 20 & $\begin{array}{l}\text { rebuild, destroy, } \\
\text { ghost town }\end{array}$ & 10 & 30 & $25.86 \%$ \\
\hline Military metaphor & $\begin{array}{l}\text { protect, fight, } \\
\text { hit, disaster }\end{array}$ & 10 & $\begin{array}{l}\text { protect, fight, } \\
\text { boom, crash, } \\
\text { disaster }\end{array}$ & 15 & 25 & $21.55 \%$ \\
\hline $\begin{array}{l}\text { Machine/technology } \\
\text { metaphor }\end{array}$ & $\begin{array}{l}\text { fix, run, } \\
\text { system, break }\end{array}$ & 10 & & 0 & 10 & $8.62 \%$ \\
\hline Other Metaphors & & 0 & $\begin{array}{l}\text { coyote, cage, } \\
\text { dark winter }\end{array}$ & 6 & 6 & $5.17 \%$ \\
\hline Crime metaphor & crime, liar & 2 & hell & 1 & 3 & $2.59 \%$ \\
\hline Total & & 63 & & 53 & 116 & $100.00 \%$ \\
\hline
\end{tabular}

Hero metaphor accounts for the major part, followed by construction metaphor. They occupy 36.21 percent and 25.86 percent respectively. Military metaphor also occupies a certain proportion, nearly 10 percent. Machine/technology metaphor, crime metaphor and some other metaphors make up minor categories. In reference to these frequent metaphors identified in Trump's discourses, detailed qualitative analysis will be performed as follows.

After processing data, we found that Trump preferred to use these seven types of conceptual metaphors. According to the ideological square, this study divides these seven types into three catalogues according to his different ideology tendencies towards "us" and "them". (1) Metaphors in catalogue one demonstrated the struggle between "us" and "them", which clearly shows the central idea of ideology square. They constantly magnify "our" strengths, disguise "our" shortcomings, and at the same time amplify "their" shortcomings to cover "their" strengths. Military metaphor, construction metaphor and machine/technology metaphor belong to this category. In such a strong contrast, "our" advantages become more and more prominent, while "their" 
shortcomings will become more and more prominent, through which the speaker could easily persuade and manipulate his audience to achieve certain purposes. (2) Catalogue two contains metaphors that only apply to "we". Under this category, discourse users focus on complimenting "our" words and actions and covering up "our" shortcomings. Hero metaphor belongs to this category. In order to realize his purposes, the speaker emphasizes "our" strengths and achievements to gain the trust of the audience and persuade them to support him. (3) Catalogue three consists of metaphors that only apply to "them". Discourse users choose metaphors with derogatory meanings and exaggerate "their" mistakes, which can obscure "their" contributions. Crime metaphor and some other metaphors fall into this category. The speaker claims that "they" threaten the interests of the audience, making "their" image more negative in the eyes of the audience, which in turn increases people's trust in "us". This also serves to persuade the audience and convey the speaker's own ideology.

Table 3. Types of metaphors used in Trump's statements in 2020 presidential election debates

\begin{tabular}{|c|c|c|c|}
\hline Ideology Tendencies & Types of Metaphors & & \\
\hline "we" and "them" & Construction metaphor & Military metaphor & Machine/technology metaphor \\
\hline "we" & Hero metaphor & & \\
\hline "them" & Crime metaphor & Other metaphors & \\
\hline
\end{tabular}

\subsection{The Opposition Between "Us" and "Them"}

The Ideological Square introduces the method to express ideology of two interest groups who is against with each other. Through metaphors, Donald Trump created a stark image of "us" and "them" out of his political purposes, then elevated "our" camp and belittled "their" camp.

\subsubsection{Construction Metaphor}

Construction metaphors represent abstract and complex things as architectures that can be constructed, built, and rebuilt, but can also be destroyed and ruined. In this sense, architectures can be source domain mapping to the target domain, the state and society. Under the concept system of architectural metaphor, there are not only buildings and builders, but also related vocabulary such as construction, destruction, and reconstruction.

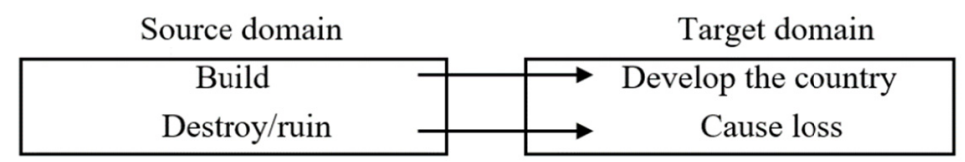

Figure 3. Cross-domain mapping in construction metaphor

Construction metaphor is also common in Trump's discourse. As the United States was facing an economic recession, there are strong calls to revive the country's economy. Trump used construction metaphors to express his views on the country's economic development strategy. He used construction metaphors to explain political strategy and express his desire to make America strong again under his administration (Wang, 2018). He implied that the future of American economy was strong and stable, suggesting that the people need to support him and work together with him. During the presidential election debate, when Trump made comments about "our" side, he always displayed his patriotism and shown his confidence in making the country prosperous and powerful.

(1) So we built the greatest economy in history.

(2) We got hit, but now we're building it back up again.

(3) A rebuilding of the military, including Space Force and all of the other things.

He constantly maintained the verb "build" to describe the process of reviving America as a process of construction as in sentence (1) and (2). This not only showed his and Republican Party's determination to develop the United States, but also highlighted the rationality of the policies he will implement, which catered to the people's desire to develop economy and make the country prosperous. On the contrary, he chose words like "destroy", antonym of "construct" to describe his rival, Democratic candidate, Biden, and argued that their actions cause loss to America. He accused them of "destroying" and "ruining" the country which was supposed to be a building.

(4) He will destroy this country. 
(5) This guy will close down the whole country and destroy our country.

Examples were shown in sentences (4) and (5). He stressed that the Democrats were doing everything they could to undermine the national economy and they were to blame for the economic decline. What they were doing was to destroy a building, the United State. Through those words, he succeeded in causing panic among American people and turn them to the Republican Party to seek help.

\subsubsection{Military Metaphor}

The choice of war-related metaphors reflects the particular intentions of the text producer and a particular ideology. In Trump's statements in in 2020 Presidential Election Debates, high frequency and dominance of the military metaphor was an outstanding feature that impact on the socio-cognitive models underlying. Military metaphor uses war related words to map wars filled with use violence, assault, and killing as the source domain to the struggles of groups and organizations for a certain political, economic, and other purposes as the target domain so that establish a kind of cognition. The concept of metaphor is systematic, and the language we use to talk about this aspect of the concept is systematic (Lakoff, 2003). War metaphor embodies abundant word, including the parties involved in the war, the process of war, and the outcome of the war.

The mind of language users is intimately linked with discourse and other social practices in the context (van Dijk, 1998). Social context is of great significance in explaining the role of cognition in the selection of specific metaphors. The emergence of war and the relationship of interests are inseparable. The collected data occurred during the US presidential election, which was indeed the lingering competition of Democratic Party and the Republican Party. This process was like a tense war. Therefore, Trump used the election as a target domain, war as a source domain to establish a cross-domain mapping. Duban (2018) also put forward a similar view that the competition of different political parties in political elections is like a war.

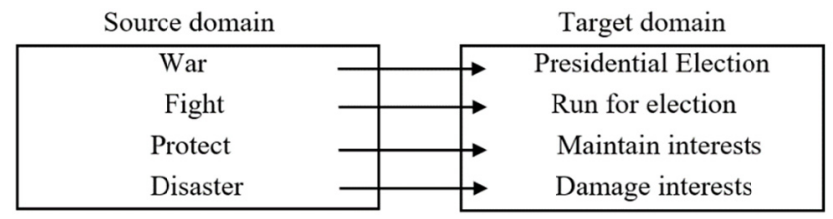

Figure 4. Cross-domain mapping in military metaphor

In elections, the fierce competition between different political parties often comes from ideological conflicts. Ideological differences between groups could often be revealed during the process of vying for membership and the recruiting of new members, or persuading outsiders. These conflicts of interest and open conflict usually imply competition (van Dijk, 1998). By depicting the presidential election as a war, he emphasized the urgent situation the United States of America was confronted with. Democrats and Republicans have strong conflicts of interest in the election and both of them tried to persuade voters to vote for them. According to this, he pitted the Republicans against the Democrats as there are always opponents in a war. As a Republican, Trump hoped that Republican Party could win the control power, so he established Republicans as "our" figure and Democrats as "their" figure in his discourse.

America has a huge grassroots base, which will make a big difference in the election. To win the support from the American grassroots, Trump lavished praise on the "our" camp, turned himself into a figure who can maintain people's interests to exert all one's energies to win the support of them.

(6) We have to protect our seniors. We have to protect our elderly. We have to protect, especially, our seniors with heart problems and diabetes problems, and we will protect them.

(7) But despite going through all of these things, where I had to fight both flanks and behind me and above.

In sentence (6), Trump declared that he loved his people and his country, and that they shared common interests. He and the Republican served the people heart and soul for they represented the interests of all Americans. With some populist characteristics, Trump touted his patriotism to win the favor of public so that manipulate them to vote for the Republican. In sentence (7), Trump molded himself as someone who "fight" for interests of the state and people. He and Republicans did everything to revive American. Only they control the country could Americans get benefit. Such words made it easier to convince Americans that and only under the leadership of the Republican Party could the United States be revived. On the other hand, Trump had been belittling the "their" image, exaggerating their shortcomings, ignoring their advantages. He intended to reduce people's trust in his 
opponents through discourses, so as to achieve the political purpose of wooing the people.

(8) If he's elected, the stock market will crash.

Trump kept fiercely attacking his rival, Biden and the Democratic, which also reveals the characteristics of populism, exclusivity. Tied his interests with the American people's, he intentionally depicted Democrats as "enemies" and accused them for menacing Americans' interest, as it shown in example (8), conveying the idea that supporting the Democrats was injurious to the public. By amplifying the negative image of the Democratic Party, he intended to make people more inclined to the Republican Party than to the Democratic Party in order to achieve more support.

\subsubsection{Machine/Technology Metaphor}

A system is a complex whole consisting of many scattered parts. In machine metaphor, a system or a machine as source domain is often mapped to the target domain, a country and society. This system or machine may go wrong, crash, and in turn it can be repaired, restored or patched. Machines are controlled by an individual, so machine metaphors tend to lead people to believe that the leader is omniscient.

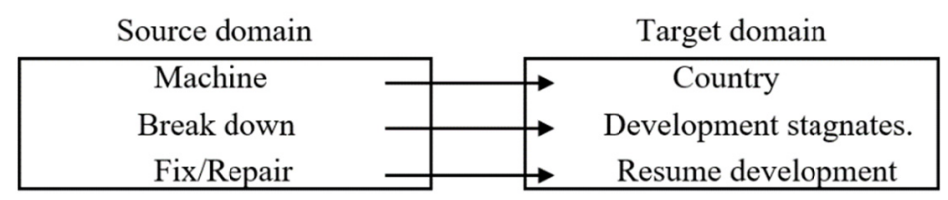

Figure 5. Cross-domain mapping in machine/technology metaphor

America is a working machine. To run smoothly, it needs an operator. That is, a leader. Faced with many problems, Trump believed that he together with Republicans became the "operator". They had the power to control the machine. Thus, it proved his and "our" rationality of controlling the country. After describing himself as an "operator" to emphasize the justice of controlling power, Trump believed he has an unshakable responsibility for how the country, the machine, operated.

(9) I've already fixed it to an extent.

(10) you can't fix the economy until you fix the COVID crisis

As shown in example (9) and (10), he claimed that whenever there was any problem in the country, he would repair the machine and get the country back to working order. Through these metaphors, he highlighted his patriotism and contribution to the country and society, deepened people's trust in his administration to win more support.

Exclusivity made Trump excluded Biden and the Democratic all from ruling power. He claimed that they do not have the power to operate the machine, in other words, they could not master state power.

(11) We've done things that you never even thought about — including fixing the broken military that you gave me.

Besides, they were the reason why the country's development had been stagnant and "broken" the operation of the country as in example (11). In this way, Trump succeeded in arousing the public's resentment against Biden and the Democratic Party and persuaded them to give up supporting it.

\section{2 "Us" Metaphor}

In the ideological square, "our" image is commendatory. Therefore, in some metaphorical categories where only positive words exist, discourse users can easily achieve certain goals by enlarging "our" image.

Due to positive implications, hero metaphors could commonly be seen in Trump's statements in in 2020 Presidential Election Debates. A hero has the responsibility to save the people. He can lead people to achieve great accomplishment, or he can do one sensational thing benefiting a state or society by himself. At the same time, the hero is also an ordinary person, in the process of reaching the goal, he needs to work hard, and may also encounter many obstacles which need to be solved.+ 


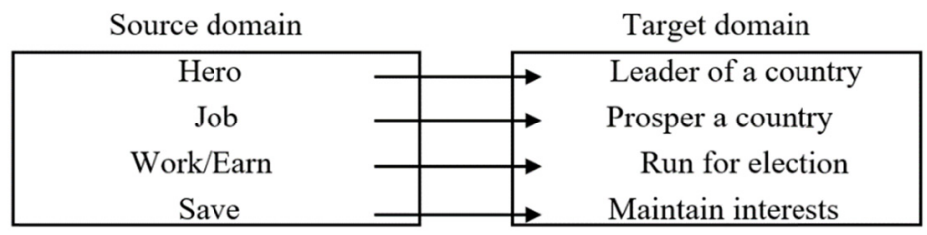

Figure 6. Cross-domain mapping in hero metaphor

During the presidential election, Trump wanted to project a positive image and show his patriotism. He established a mapping between the source domain, heroes and the target domain, himself and the Republicans, though which he could parade his contribution in order to strive for support, consolidate power, and maintain his own interests.

(12) Economically, we saved it, and I saved it again a number of months ago when oil was crashing because of the pandemic.

(13) We saved our oil industry, and now it's very vibrant again.

It is hero's duty to safeguard nation's interest. In example (13) and (14), through the emphasis on that he safeguarded the national interests, Trump claimed that he and the Republicans are heroes, and all of their policy principles were aimed at safeguarding national interests, which shown his "patriotism".

Every hero has his own great cause, or goal. His task is to work hard to achieve this goal. He made use of the Americans' desire for development, trying to get them to support his development plan. However, as one of the ordinary people, in the process of completing a task or achieving a goal, he ought to work very hard and overcome difficulties happening constantly.

(15) Many of your Democrat governors said President Trump did a phenomenal job.

(16) I've done a great job as the President, and I'll have 25, 35,000 people show up at airports.

(17) We have done an incredible job environmentally.

Trump presented that under his leadership, he worked hard to do his "job", prospering the United States in sentence (15), (16) and (17). He intended to convince voters that the Republicans would bring about a revolution, and change fate of the United States.

\section{3 "Them" Metaphor}

In ideology square, once "their" shortcomings and mistakes are amplified, "our" shortcomings can be covered. Therefore, discourse users stand on this perspective to shirk their responsibility.

\subsubsection{Crime Metaphor}

Behaviors that endanger national and social interests are defined as crimes. Though the forms of crime are diverse, crimes always bring damaging consequences. This category contains various words that represent crime. Each of them will cause losses to the people and society.

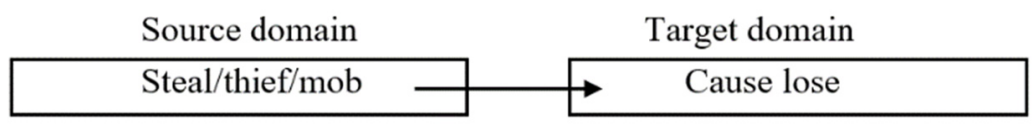

Figure 7. Cross-domain mapping in Crime Metaphor

In the presidential election, Democrats and Republicans have their own principles, policies, and measures for governing the country which safeguarded the different interests of the two parties. Trump claimed that the Republican Party defended the national interest while his rival Democratic Party endangered it. Therefore, he used criminal behaviors as the source domain to establish a mapping to the target domain, Republicans' political activities.

(18) The numbers are going up 100, 150, 200 percent, uh, crime.

(19) Joe, you're the liar. 
(20) Your 401k's will go to hell and it'll be a very, very, sad day for this country.

During the presidential elections, Trump regarded Biden and Democrats as criminals, arguing that their committed a crime that endangered national interests, for example in sentence (18). By accusing Biden as a "liar" in sentence (19) and describing Biden's administration as "hell" in sentence (20), he subtly shirked his responsibilities and persuaded people to firmly believe that all the problems arising in the United States were caused by Biden and the Democrats. It was all "their" fault. Gradually, Americans accepted the view that it was the Democratic Party, not the Republican Party always did harm to national interest and hindered the country's development. They became more and more distrustful of the Democratic Party and turned to the Republican Party to vote for the Republican Party.

\subsubsection{Other Metaphors}

In addition to the five categories of metaphors mentioned above, Trump also used other metaphors such as animal metaphor and color metaphor.

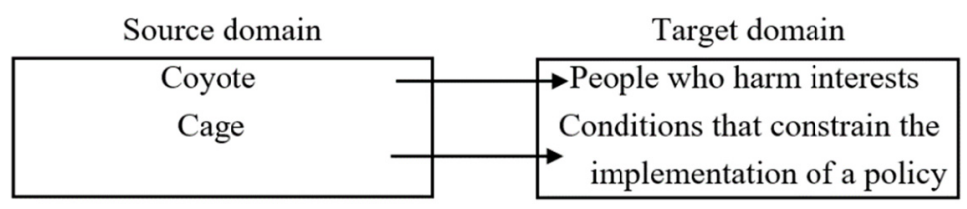

Figure 8. Cross-domain mapping in animal metaphor

(21) Children are brought here by coyotes and lots of bad people, cartels, and they're brought here, and they used to use them to get into our country.

(22) They built cages. You know, they used to say I built the cages, and then they had a picture in a certain newspaper, and it was a picture of these horrible cages. And they said look at these cages.

Trump used metaphors to shape a negative image of his opponent. In sentence (21), Trump conveyed his bias against the Democratic Party. Because they stood in the way of his presidency and his hold on power, he was at pains to pretend being with grassroots in order to prove that the Democratic Party did harm to American people. Trump accused that the Democrats "built cages" in sentence (22) to constrain the implementation of his policies and the development of America. He is adept at diverting discontent from him to the Democrats. Trump's ultimate goal was to stir up disaffection with Democrats and win votes for himself.

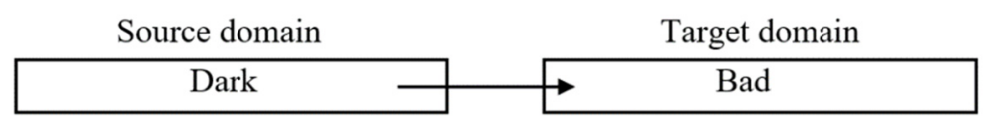

Figure 9. Cross-domain mapping in color metaphor

(23) I don't think we're going to have a dark winter at all.

Light color is usually mapped to good conditions, while dark color is usually mapped to bad conditions. In Trump's discourse in the presidential election debate, he described the current situation as "dark winter" in sentence (23) to convey to the public an idea that they were facing terrible condition and all the trouble were created by the Democratic rival. Through metaphor he spread fear among the people. Thus, he could persuade the public to trust that he and his party had the power to solve all the problems and bring a bright future.

\section{Conclusion}

By identifying the metaphors used in Trump's statements in 2020 Presidential Election Debates, it is found that these metaphors can be divided into six categories according to different source metaphors, namely military, hero, construction crime, machine/technology and other metaphors. Trump manipulates people from the cognitive level by establishing a cross-domain mapping between the people's existing experience and political ideas to achieve his political goals. Then, the study introduces the Ideology Square to the analysis of the ideology tendency of the "we" and "them" in Trump's metaphors. Trump took advantage of Americans' psychology that they were urgent to solve development problems and revitalize American. The use of metaphors magnified the 
contributions of the Republican Party, masked the defects of the Republican Party, exaggerated the disadvantages of the Democratic Party, and concealed the merits of the Democratic Party. In this way, Trump weakened the people's trust in the Democratic Party and persuaded people to support the Republican Party. Moreover, in metaphors, Trump declared himself as one of the grassroots. He claimed to be a member of the ordinary people, representing their interests and willing to fight for their interests. At the same time, some populism characteristics were also reflected. Seeming, he regarded people as his priority and promoted his "patriotism", showing "exclusiveness" in his discourse. In essence, he controlled the public and engaged them in the political process for his own benefit.

Though this study employed qualitative method to make conclusions reliable. During the process of metaphor identification, interpretation and explanation, subjectivity could not be completely avoided. A more objective research framework needs to be proposed. Besides, this study focused on the speakers to explore his ideology and cognitive structure carried by metaphors he used. Future studies can focus on the recipients of metaphors to investigate whether metaphors can convey the speaker's ideology and cognitive structure to the listeners.

\section{References}

Bayram, F. (2010). Ideology and Political Discourse: A Critical Discourse Analysis of Erdogan's Political Speech. ARECLS, 7, 23-40.

Bhatia, A. (2006). Critical discourse analysis of political press conferences. Discourse \& Society, 17(2), 173-203. https://doi.org/10.1177/0957926506058057

Bonilla, J. F. (2020). Critical discourse analysis of Trump across time. Sustainable Multilingualism, 16, 1-20. https://doi.org/10.2478/sm-2020-0001

Caballero-Mengibar, A. (2015). Critical discourse analysis in the study of representation, identity politics and power relations: A multi-method approach. Communication \& Society, 28(2), 39-54. https://doi.org/10.15581/003.28.2.39-54

Charteris-Black, J. (2004). Corpus Approaches to Critical Metaphor Analysis. New York: Palgrave Macmillan. https://doi.org/10.1057/9780230000612

Dirven, R., Polzenhagen, F., \& Wolf, H.-G. (2005). Cognitive Linguistics, Ideology, and Critical Discourse Analysis. In D. Geeraerts \& H. Myckens (Eds.), Handbook of Cognitive Linguistics. Oxford: Oxford University Press.

Duban, N. B. (2018). Metaphorical mapping in Donald Trump's discourse (exemplified by his public addresses during the 2015-2016 presidential campaign in the USA). Молодий вчений, 2(54), 192-197.

Fairclough, N. (1995). Critical discourse analysis: The critical study of language. New York: Longman publishing.

Garcia, S. (2017). By Tweet and By Speech: An Examination of Values in Donald Trump's Metaphor. Doctorial Dissertation, Texas, the Honors College.

Halliday, M. A. K. (2000). An Introduction to Functional Grammar. Beijing: Foreign Language Teaching and Research Press.

Harb, G. K., \& Serhan, Y. M. (2020). Exploring the Use of Covid-19 as a New Pre-Text in Trump's Political Discourse. Journal of Humanities and Social Sciences Studies, 2(5), 20-30.

Hart C. (2008). Critical discourse analysis and metaphor: Toward a theoretical framework. Critical Discourse Studies, 5(2), 91-106. https://doi.org/10.1080/17405900801990058

Heritage, F. (2018). "When they go low, you go high": A Metaphor and Metonomy-led Analysis of the Second American Presidential Debate between Hillary Clinton and Donald Trump. Masters Dissertation, Birmingham, University of Birmingham.

Jian, S. F. (2018). Critical Discourse Analysis of President Trump's Inaugural Speech. Journal of University of Shanghai for Science and Technology (Social Sciences Edition), 40(03), 230-235.

Lakoff, G., \& Johnson, M. (2003). Metaphors We Live By. London: The University of Chicago Press. https://doi.org/10.7208/chicago/9780226470993.001.0001

Lakoff, G., \& Turner, M. (1989). More than Cool Reason: A Field Guide to Poetic Metaphor. Chicago: The University of Chicago Press. https://doi.org/10.7208/chicago/9780226470986.001.0001

Lamb, E. C. (2013). Power and resistance: New Methods for Analysis across Genres in Critical Discourse 
Analysis. Discourse \& Society, 24(3), 334-360. https://doi.org/10.1177/0957926512472041

Landau, M. J., Meier, B. P., \& Keefer, L. A. (2010). A metaphor-enriched Social Cognition. Psychological Bulletin, 136(6), 1045-1067. https://doi.org/10.1037/a0020970

Li, P., \& Li, Y. (2011). A Brief Analysis of Overlapping Between Structural Metaphor, Orientational Metaphor and Ontological Metaphor. Journal of Chengdu Normal University, 27(02), 60-63.

Mohammadi, M., \& Javadi, J. (2016). A Critical Discourse Analysis of Donald Trump's Language Use in US Presidential Campaign. International Journal of Applied Linguistics \& English Literature, 6(5), 1-10. https://doi.org/10.7575/aiac.ijalel.v.6n.5p.1

Oppermann, K., \& Spencer, A. (2013). Thinking Alike? Salience and Metaphor Analysis as Cognitive Approaches to Foreign Policy Analysis. Foreign Policy Analysis, 9, 39-56. https://doi.org/10.1111/j.1743-8594.2011.00167.x

Pilyarchuk, K., \& Onysko, A. (2018). Conceptual Metaphors in Donald Trump's Political Speeches: Framing his Topics and (Self-)Constructing his Persona. Onysko Colloquium: New Philologies, 3(2), 39-56. https://doi.org/10.23963/cnp.2018.3.2.5

Purvis, T., \& Hunt, A. (1993). Discourse, Ideology, Discourse, Ideology, Discourse, Ideology... The British Journal of Sociology, 44(3), 473-499. https://doi.org/10.2307/591813

The Pragglejaz Group. (2007). MIP: A method for identifying metaphorically used words in discourse. Metaphor and Symbol, 22(1), 1-39. https://doi.org/10.1080/10926480709336752

Van Dijk, T. A. (1998). Ideology: A multidisciplinary approach. London. England: Sage Publications.

Van Dijk, T. A. (2001). Critical Discourse Analysis. In D. Schiffrin, D. Tannen \& H. E. Hamilton (Eds.), The Handbook of Discourse Analysis. Malden, Massachusetts: Blackwell Publishers Inc.

Van Dijk, T. A. (2005). Contextual knowledge management in discourse production. In R. Wodak \& P. Chilton (Eds.), A new agenda in (critical) discourse analysis. Amsterdam: John Benjamins. https://doi.org/10.1075/dapsac.13.07dij

Van Dijk, T. A. (2006). Ideology and discourse analysis. Journal of Political Ideologies, 11(2), 115-140. https://doi.org/10.1080/13569310600687908

Wang, Y. Y. (2019). An Analysis of Trump's 2016 Campaign Speeches from the Perspective of Social Force in Force-dynamics Theory. Theory and Practice in Language Studies, 9(9), 1118-1124. https://doi.org/10.17507/tpls.0909.07

Wodak, R., \& Meyer, M. (2002). Methods of Critical Discourse Analysis. California: Sage Publications. https://doi.org/10.4135/9780857028020

Wodak, R., \& Meyer, M. (2008). Critical Discourse Analysis: History, Agenda, Theory, and Methodology. In R. Wodak \& M. Meyer (Eds.), Methods of Critical Discourse Analysis. London: SAGE Publications.

Wolf, H.-G., \& Polzenhagen, F. (2003). Conceptual Metaphor as Ideological Stylistic Means: An Exemplary Analysis. In R. Dirven, F. R. Roslyn \& P. M. Martin (Eds.), Cognitive Models in Language and Thought: Ideology, Metaphors and Meanings. Berlin: Mouton de Gruyter.

Woodside-Jiron, H. (2004). Language, Power, and Participation: Using Critical Discourse Analysis to Make Sense of Public Policy. In R. Rogers (Ed.), An Introduction to Critical Discourse Analysis in Education. New York: Routledge.

Wu, J. G., Gong, C., \& Song, Y. (2020). Investigating Political Discourse from the Perspective of CMA: A Case Study on Trump's Speeches. Journal of Foreign Languages, 43(3), 80-88.

Xin, B., \& Liu, C. (2017). On van Dijk's Socio-cognitive Discourse Analysis. Foreign Language Research, 5 , $14-19$.

Zhang, Y. C. (2017). Transitivity Analysis of Hillary Clinton's and Donald Trump's First Television Debate. International Journal of Applied Linguistics \& English Literature, 6(7), 65-72. https://doi.org/10.7575/aiac.ijalel.v.6n.7p.65 


\section{Copyrights}

Copyright for this article is retained by the author, with first publication rights granted to the journal.

This is an open-access article distributed under the terms and conditions of the Creative Commons Attribution license (http://creativecommons.org/licenses/by/4.0/). 